Table 1. The prey of Pipistrellus coromandra in Auroville, Tamil Nadu, southern India

\section{PREY OF THE INDIAN PIPISTRELLE BAT Pipistrellus coromandra (Gray) AT AUROVILLE, SOUTHERN INDIA}

\section{Mario Eric Ramanujam ${ }^{1}$ and Boris Verzhutskii ${ }^{2}$}

\author{
${ }^{1}$ Principal Investigator (Fauna) ECTDEF Project, Pitchandikulam \\ Bio-Resource Centre, Auroville, Pondicherry 605101, India \\ Address for correspondence: Research Associate, Gratitude \\ Avian Rehabilitation, Auroville, Pondicherry 605101, India \\ ${ }^{2}$ Entomologist, Palmyra Project, Aurobrindavan, Auroville, \\ Pondhicherry 605111, India \\ Email: ${ }^{1}$ tdef@auroville.org.in, ${ }^{2}$ palmyra@auroville.org.in
}

The prey and feeding habits of Pipistrellus coromandra has been recorded in general (Bates \& Harrison, 1997), as well as in specific areas - for example, in Bihar (Sinha, 1986) and in central and western India (Brosset, 1962). This report concerns the prey spectrum of this species in Auroville, in the close vicinity of Pondicherry.

Methods: The diurnal roots of Pipistrellus coromandra includes, among others, the gaps between palm leaf fronds used to thatch roofs of houses. One such accessible roost occurs in a residence at the community of Aspiration $\left(11^{0} 59^{\prime} \mathrm{N}\right.$ \& $79^{0} 50^{\prime} \mathrm{E}$ ) in Auroville which is $c a$. $8 \mathrm{~km}$ north of Pondicherry city. Seventy copropieces were collected between January and December 2003. A binocular microscope and established literature on insects (Borror, 1992; Mani, 1990) allowed an analysis of all arthropod remains.

The frequency of particular components of food consumed was assessed according to a pre-established system in place for calculating the trophic connections of fauna in this region (Verzhutskii \& Ramanujam, 2002). This methodology recognizes four classes: basic food (>20\%), constant food (5-20\%), supplementary food $(1-5 \%)$, and chance food $(<1 \%)$.

Results: Two-hundred-and-sixty-seven prey items were identified in the faeces. Basic food consisted of Lepidoptera (31.08\%) and Coleoptera (22.09\%). Among the 83 Lepidoptera, the following were identified: 48 Herse convolvuli (Family Sphingidae), three Achaea janata, four Othreis fullonia, three Spodoptera mauritia, one Spiramea rotata (Family Noctuidae) and two Melanitis leda (Family Satyridae). Among the 59 Coleoptera, 42 were Holotrichia spp. (Scarabaeidae: Melolonthinae) and three Copris sp. (Scarabaeidae: Scarabaeinae $=$ Coprinae) .

Constant food comprised of Mantodea (10.86\%), Blattaria (10.48\%), Hemiptera $(7.11 \%)$, Orthoptera (5.99\%) and Isoptera (5.61\%). Supplementary food was Araneae (2.24\%), Neuroptera $(1.87 \%)$ and Hymenoptera (1.12\%). Chance food consisted of Odonata and Diptera $(0.74 \%$ each). Spiders (Araneae) were the only non-insect arthopods recorded. For details refer to Table 1.

\begin{tabular}{llll}
\hline Prey & $\#$ & $\%$ & Category \\
\hline Araneae (Spiders) & 6 & 2.24 & SF \\
Odonata (Dragonflies \& Damselflies) & 2 & 0.74 & OF \\
Orthoptera (Grasshoppers, Crickets, etc.) & 16 & 5.99 & CF \\
Mantodea (Mantids) & 29 & 10.86 & CF \\
Blattaria (Cockroaches) & 28 & 10.48 & CF \\
Isoptera (Termites) & 15 & 5.61 & CF \\
Hemiptera (Bugs) & 19 & 7.11 & CF \\
Neuroptera (Lacewings \& Ant-lions) & 5 & 1.87 & SF \\
Coleoptera (Beetles) - 1 & 59 & 22.09 & BF \\
Diptera (Flies) & 2 & 0.74 & OF \\
Lepidoptera (Butterflies \& Moths) - 2 & 83 & 31.08 & BF \\
Hymenoptera (Ants, Bees \& Wasps) - 3 & 3 & 1.12 & SF \\
& 267 & & \\
\hline
\end{tabular}

\# - Number consumed; BF- Basic food (>20\%); CF - constant food (5-20\%); SF - Supplementary food (1-5\%); OF - chance Food (<1\%).

1 - 42 Holotrichia spp., 3 Copris sp., 14 Unidentified;

2 - 48 Herse convolvuli, 3 Achae ajanata, 4 Othreis fullonia, 3 Spodoptera mauritia, 1 Spiramea rotata, 2 Melanitis leda, 22 Unidentified;

3 - Winged Formicidae;

Discussion: The principal prey of $P$. coromandra in Bihar was said to be small ants and flies (Sinha, 1986) and small flies in central and western India (Brosset, 1962). Here, along the Coromandel (East) Coast of southern India, the principal prey was recorded to be Butterflies and Moths (31.08\%) and Beetles $(22.09 \%)$, with ants and flies accounting for a paltry $1.12 \%$ and $0.74 \%$ respectively. This shows a marked divergence from the diet recorded in the aforementioned areas. These results also show that $P$. coromandra can feed on larger insects than was previously supposed.

\section{REFERENCES}

Bates, P.J.J. and D.L. Harrison (1997). Bats of the Indian Subcontinent. Harrison Zoological Museum Publication, 258pp.

Borror, D. (1992). An Introduction to the Study of Insects. Harcourt Brace College Publishers, USA, 876pp.

Brosset, A. (1962). The bats of central and western India. Part II. Journal of the Bombay Natural History Society 59(3): 707-746.

Mani, M. (1990). General Entomology. Oxford \& IBH Publishing, New Delhi, 912pp.

Sinha, Y.P. (1986). The Bats of Bihar: taxonomy and field ecology. Records of the Zoological Survey of India. Miscellaneous Publication. Occassional paper 77: 1-60.

\section{ACKNOWLEDGements}

We wish to thank the European Commission's Tropical Dry Evergreen Forest Project, Pithchandikulam Bioresource Centre and Shakti Herbarium for supplying the materials and means to carry out faunal assessments in the Kaliveli Watershed region.

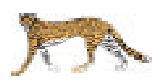

